\title{
A semi-empirical relationship for the small-strain shear modulus of soft clays
}

\author{
Vashish Taukoor ${ }^{1, *}$, Cassandra J. Rutherford ${ }^{2}$, and Scott M. Olson ${ }^{1}$ \\ ${ }^{1}$ University of Illinois at Urbana-Champaign, Department of Civil and Environmental Engineering, 61801, USA \\ ${ }^{2}$ Iowa State University Department of Civil, Construction and Environmental Engineering, 50011-1066, USA
}

\begin{abstract}
The small-strain shear modulus $\left(\mathrm{G}_{\max }\right)$ is a soil property that has many practical applications. The authors compiled a database of $\mathrm{G}_{\max }$ measurements for 40 normally consolidated to slightly overconsolidated low to high plasticity clays. Using these data, the authors propose a semiempirical relationship between $G_{\max }$, effective stress $\left(\sigma_{v}^{\prime}\right.$ or $\left.\sigma_{c}^{\prime}\right)$, preconsolidation stress $\left(\sigma_{p}^{\prime}\right)$ and insitu void ratio (e $\left.\mathrm{e}_{0}\right)$ for four ranges of plasticity index $\left(\mathrm{I}_{\mathrm{p}}\right)$ : $\mathrm{I}_{\mathrm{p}}<30 \%, 30 \% \leq \mathrm{I}_{\mathrm{p}}<50 \%, 50 \% \leq \mathrm{I}_{\mathrm{p}}<80 \%$ and $80 \% \leq \mathrm{I}_{\mathrm{p}}<120 \%$. With results from bender element tests on a Gulf of Mexico clay subjected to multiple load-unload consolidation loops, the authors were able to validate the proposed relationships for $30 \% \leq \mathrm{I}_{\mathrm{p}}<50 \%$ and $50 \% \leq \mathrm{I}_{\mathrm{p}}<80 \%$. The proposed relationship for $30 \% \leq \mathrm{I}_{\mathrm{p}}<50 \%$ and $50 \% \leq$ $\mathrm{I}_{\mathrm{p}}<80 \%$ captures changes in laboratory $\mathrm{G}_{\max }$ resulting from variations in effective stress $\left(\sigma_{\mathrm{c}}^{\prime}\right)$, maximum past stress $\left(\sigma_{v, \max }^{\prime}\right)$, and void ratio. The proposed relationships are a simple and efficient tool that can provide independent insight on $\mathrm{G}_{\max }$ if the stress history of a clay is known, or on stress history if $\mathrm{G}_{\max }$ is known.
\end{abstract}

\section{Introduction}

The small-strain shear modulus, $\mathrm{G}_{\max }$, refers to the ratio of shear stress to shear strain at strains $<10^{-3} \%$. It is a fundamental soil property that has many practical implications. For instance, the proper evaluation of $\mathrm{G}_{\max }$ is a pre-requisite for reliably assessing stress-strain relationships of natural soils (e.g., [1]), specimen disturbance (e.g., [2]), ground movement (e.g., [3], [4]), site response analysis (e.g., [5]) and numerical modelling (e.g., [6], [7])

Owing to the development of techniques to measure $\mathrm{G}_{\max }$ in the laboratory (e.g., resonant column, torsional shear, bender elements integrated in oedometer and triaxial setups) and in the field (e.g., sCPTu, cross-hole, MASW), a significant number of research works focusing on the $\mathrm{G}_{\max }$ of both coarse-grained and fine-grained soils has been undertaken in the last couple of decades. This paper focuses on the $G_{\max }$ of soft clays.

Based on the extensive works done on the $\mathrm{G}_{\max }$ of soft clays, spanning almost 60 years ([8] - [19]), our understanding of the controlling factors has been sharpened. These include effective stress, void ratio, plasticity index, preconsolidation stress, anisotropy (inherent and stress-induced), age of deposit, degree of saturation, cementation, thixotropy, and mineralogy.

Some researchers have attempted to provide a unifying framework pertaining to the evaluation of $G_{\max }$ of clays ([20] - [22]). However, it is quite challenging to propose a framework that considers all the abovementioned factors. This paper provides a framework that takes into account effective stress, $\sigma_{c}^{\prime}$, preconsolidation stress, $\sigma_{p}^{\prime}$, void ratio, $e_{0}$ and plasticity index, $I_{p}$. The framework is based on a database consisting of 40 different clays having a range of $I_{p}$ and tested both in-situ and in the laboratory. The resulting semi-empirical correlations are compared with the results of bender element tests run on a Gulf of Mexico (GOM) clay mounted in a triaxial apparatus.

\section{Relating $G_{\max }, \sigma^{\prime}, \sigma_{p}^{\prime}, e$, and $I_{p}$ in clay}

The small-strain shear modulus of a saturated clayey soil is controlled by the stiffness of the matrix, which depends on effective stress, preconsolidation stress, void ratio, stress history, strength anisotropy, plasticity index and mineralogy (among others). Quantifying the $\mathrm{G}_{\max }$ of a clay matrix is a complicated task for two reasons:

1. $\mathrm{G}_{\max }$ is dependent to varying degrees on a number of factors;

2. A significant number of those factors are interdependent. For example, higher consolidation stress corresponds to smaller void ratio; higher preconsolidation stress corresponds to smaller void ratio; higher plasticity index corresponds to smaller particle size and larger initial void ratio; and so on.

Clay structure is primarily influenced by effective stress, preconsolidation stress, plasticity index, and void ratio (e.g., [23]), and from a practical point of view, it is relatively easy to quantify these properties. Therefore, a

* Corresponding author: taukoor2@illinois.edu 
relationship between $\mathrm{G}_{\max }, \sigma^{\prime}, \sigma_{\mathrm{p}}^{\prime}$, e, and $\mathrm{I}_{\mathrm{p}}$ is both justified and practically useful.

\subsection{Why is $G_{\max }$ a function of both $\sigma^{\prime}$ and void ratio?}

Small-strain stiffness depends on how densely packed the soil particles are. The closer the particles, the denser the fabric, the less likely it is to deform in shear, and the larger the stiffness. For a clay, both the effective stress and the void ratio control the fabric. The larger the effective stress or the smaller the void ratio, the closer the particles are packed in the soil matrix and the higher the stiffness ([9]). Therefore, the relationship shown in Equation 1 is valid:

$$
G_{\max } \propto\left(\sigma^{\prime} / e\right)
$$

\subsection{Why is $G_{\max }$ a function of $\sigma_{p}^{\prime}$ ?}

The undrained shear strength $s_{u}$ of a clayey soil depends on its $\sigma_{p}^{\prime}$ irrespective of $I_{p}$ and confining pressure (e.g., [24]). The undrained shear strength of a clayey soil often is related to its Young's modulus, E, (e.g., [25]) because the higher the shear strength, the steeper the initial stressstrain response and hence the larger the value of $E$. The shear stiffness being a function of $E$, it follows that $G_{\max }$ is a function of $s_{u}$ and hence $\sigma_{p}^{\prime}$. Conceptually, the higher the preconsolidation pressure, the more contacts exist in a clay matrix and the stiffer it is. Therefore, the relationship shown in Equation 2 is valid:

$$
G_{\max } \propto \sigma_{p}{ }^{\prime}
$$

From an extensive study of Norwegian clays, [22] showed that $\sigma_{p}^{\prime}$ correlated well with the square of the shear wave velocity, $\mathrm{V}_{\mathrm{s}}{ }^{2}$, with the coefficient of variance $\mathrm{R}^{2}$ being 0.80 . Thus, $\sigma_{\mathrm{p}}^{\prime}$ correlates well with $\mathrm{G}_{\max }$.

\subsection{Why is $G_{\max }$ a function of $I_{p}$ ?}

Clayey soils with high plasticity are predominantly composed of thin, flexible plate-shaped particles with larger relative surface areas, to which a large volume of water is adsorbed. As a result of inter-particle forces, those clays tend to have a flocculated open structure characterized by many face-to-edge contacts between particles and/or aggregated particles. The open fabric of those clays implies a higher compressibility and hence a smaller stiffness. Therefore, a higher plasticity index implies a smaller shear stiffness (e.g., [11], [13]) as suggested by Equation 3 .

$$
G_{\max } \propto \frac{1}{I_{P}}
$$

Therefore, it follows that the functional form of $\mathrm{G}_{\max }$ given by Equation 4 should be valid.

$$
G_{\max }=k \times\left(\sigma_{p}\right)^{m} \times\left(\sigma^{\prime}\right)^{n} \times\left(\frac{1}{e}\right)^{o} \times\left(\frac{1}{I_{P}}\right)^{p}
$$

where $\mathrm{k}, \mathrm{m}, \mathrm{n}, \mathrm{o}$ and $\mathrm{p}$ are fitting parameters. Based on the above, and with further reasoning (outside the scope of this paper), the functional form of $\mathrm{G}_{\max }$ shown in Equation
5 was deduced. The parameter $\mathrm{A}$ is a function of plasticity index and will be discussed later.

$$
G_{\max }=A \times\left(\sigma_{p}{ }^{\prime} \times \frac{\sigma^{\prime}}{e}\right)^{0.5}
$$

\section{Description of the tests on GOM clay}

\subsection{Apparatus and bender elements}

The testing equipment, manufactured by Wykeham Farrance/ControlsGroup, consisted of a computercontrolled servo-pneumatic system, designed to perform both monotonic and cyclic triaxial tests. The main components of the equipment are a triaxial loading frame, a cell pressure source, a back-pressure source, a PWP transducer, a data acquisition system, a computer and top and bottom caps equipped with bender elements, which are powered by wave form signal generator.

A bender element is a piezoceramic electromechanical transducer, which can convert mechanical energy (movement) either to or from electrical energy. It consists of two thin piezoceramic plates, which are rigidly bonded together with conducting surfaces between them and on the outsides. The polarization of the ceramic material in each plate and the electrical connections are such that when a driving voltage is applied to the element, one plate elongates and the other shortens. The net result is a bending displacement, which is greater in magnitude than the length changes in either of the two layers. This bending displacement produces a shear wave that propagates parallel to the length of the element into the soil specimen. On the other end of the specimen, upon receiving the shear wave, the bender element is forced to bend as one piezoceramic plate goes into tension and the other into compression. This results in an electrical signal that can be measured.

For the setup adopted for the tests described herein, the bender element integrated in the top cap was the sender and the bender element in the bottom cap was the receiver. The time interval between sending a signal ( $\left.t_{\text {sent }}\right)$ and receiving it ( $\left.\mathrm{t}_{\text {received }}\right)$ and the distance between the bender elements $(\Delta \mathrm{L})$ are used to calculate $\mathrm{V}_{\mathrm{s}}$ and subsequently $G_{\max }$, as shown in Equations 6 and 7 , respectively. Note that $\Delta \mathrm{L}$ is the distance between the bender elements, i.e., the length of the specimen minus the protrusions of the bender elements from the caps (protrusion $_{\mathrm{BE}} \approx 17.60 \mathrm{~mm}$ ). The density of a saturated specimen, $\rho_{\mathrm{T}}$, can be obtained from the void ratio, e, specific gravity, $G_{s}$ and density of water, $\rho_{\mathrm{w}}$, as shown in Equation 8.

The apparatus also consists of a cell pressure source and a back-pressure source, which are two air-pressurized cylinders that rely on an air-water interface to generate the desired pressure (up to $1000 \mathrm{kPa}$ ). The data acquisition system is capable of monitoring displacement, cell pressure and back pressure and PWP independently, and measurements are recorded by a Windows-based computer, which is used to send signals to the equipment via servo-valves. The PWP transducer records data at the base of the specimen with an accuracy of $0.1 \mathrm{kPa}$. 


$$
\begin{gathered}
V_{s}=\frac{\Delta L}{\left(t_{\text {sent }}-t_{\text {received }}\right)}=\frac{L_{\text {specimen }}-\left(2 \times \text { protrusion }_{B E}\right)}{\Delta t} \\
G_{\max }=\rho_{T} \times\left(V_{s}\right)^{2} \\
\rho_{T}=\frac{\left(G_{s}+e\right) \times \rho_{w}}{(1+e)}
\end{gathered}
$$

Specimens of GOM clay were prepared, equipped with bender elements and subjected to equal all-around consolidation stress beyond their in-situ $\sigma_{\mathrm{p}}^{\prime}$. At various consolidation stresses, with the instantaneous length of the specimen and with the instantaneous void ratio known, measurements of $\mathrm{V}_{\mathrm{s}}$ were taken. Thus values $\mathrm{G}_{\max }$ corresponding to a given set of $\sigma_{c}^{\prime}, \sigma_{v, \max }^{\prime}$ and $e$ and involving at least one unload-reload loop could be obtained.

\subsection{GOM clay and specimen preparation}

The GOM clay used was sampled during a May 2012 commercial cruise with a Jumbo Piston Core (JPC) sampler from about $3000 \mathrm{~m}$ below sea level in the Walker Ridge area of the Gulf of Mexico basin. Details about the JPC sampling technique can be found in [26]. JPC sampling yields about $30 \mathrm{~m}$ of soil enclosed in a PVC tube having an internal diameter of 4 inches $(102 \mathrm{~mm})$ and an external diameter of 4.5 inches $(114 \mathrm{~mm})$. After sampling, the tube is cut into smaller 0.9 m-long tubes, sealed at the ends and transported to the laboratory for testing.

The JPC tubes selected for testing, originating from a depth of $2.5 \mathrm{~m}$ to $15.5 \mathrm{~m}$ below the seabed, were carefully cut at two locations to the desired length using a rotating tube cutter. The tube cutter was turned slowly while applying gentle pressure such that there was no visual evidence of damage. A wire saw was passed through the two cuts and the clay was extruded in the same direction as sampling. Following extrusion, the GOM clay samples were trimmed with a wire-saw to an average diameter of $70.3 \mathrm{~mm}$ and an average height of $145.0 \mathrm{~mm}$ (average $\mathrm{H} / \mathrm{D}=2.1$ ). Each specimen was mounted on the bottom cap (equipped with a bender element) and equipped with a top cap (with bender element), vertical filter paper side drains and a latex membrane (thickness $=0.30 \mathrm{~mm}$ ). The specimens then were carefully mounted in the cyclic triaxial apparatus, back-pressure saturated (B-value > 0.97 ) and consolidated under equal all-around stress to the virgin compression zone.

Table 1summarizes the index properties of the GOM clay and some details about the testing program. Specimen GOM BE1 was first consolidated under equal all-around stress to $34 \mathrm{kPa}\left(\sigma_{\mathrm{c}}^{\prime}=34 \mathrm{kPa}, \sigma_{\mathrm{v}, \max }^{\prime}=34 \mathrm{kPa}\right)$. The confining stress $\sigma_{\mathrm{c}}^{\prime}$ was increased in steps to $155 \mathrm{kPa}$ $\left(\sigma_{\mathrm{c}}^{\prime}=155 \mathrm{kPa}, \sigma_{\mathrm{v}, \max }^{\prime}=155 \mathrm{kPa}\right)$, then decreased to 73 $\mathrm{kPa}\left(\sigma_{\mathrm{c}}^{\prime}=73 \mathrm{kPa}, \sigma_{\mathrm{v}, \text { max }}^{\prime}=155 \mathrm{kPa}\right)$, then increased to 314 $\mathrm{kPa}\left(\sigma_{\mathrm{c}}^{\prime}=314 \mathrm{kPa}, \sigma_{\mathrm{v}, \max }^{\prime}=314 \mathrm{kPa}\right)$, following which it was decreased to $81 \mathrm{kPa}\left(\sigma_{\mathrm{c}}^{\prime}=81 \mathrm{kPa}, \sigma_{\mathrm{v}, \text { max }}^{\prime}=314 \mathrm{kPa}\right)$. Thus, GOM BE1 had 2 unload-reload consolidation loops, during which 18 measurements of $\mathrm{V}_{\mathrm{s}}$ were taken.

\section{Bender element test results}

The results of the 4 bender element tests are shown in Fig. 1 in a $G_{\max }$ Vs. $\sigma_{\mathrm{v}, \max }^{\prime} \mathrm{x}\left(\sigma_{\mathrm{c}}^{\prime} / \mathrm{e}\right)$ space. It can be seen that all 4 test results fall within a relatively narrow band. This is so because all the specimens had relatively similar plasticity index. Based on the plot, a case can be made for the validity of Equation 5; for the range of $I_{p}$ tested, the data support the form of Equation 5. It can be seen that $\mathrm{G}_{\max }$ of GOM clay is a function of $\sigma_{v, \max }^{\prime} \mathrm{x}\left(\sigma_{\mathrm{c}}^{\prime} / \mathrm{e}\right)$ regardless of whether the clay is normally consolidated or overconsolidated.

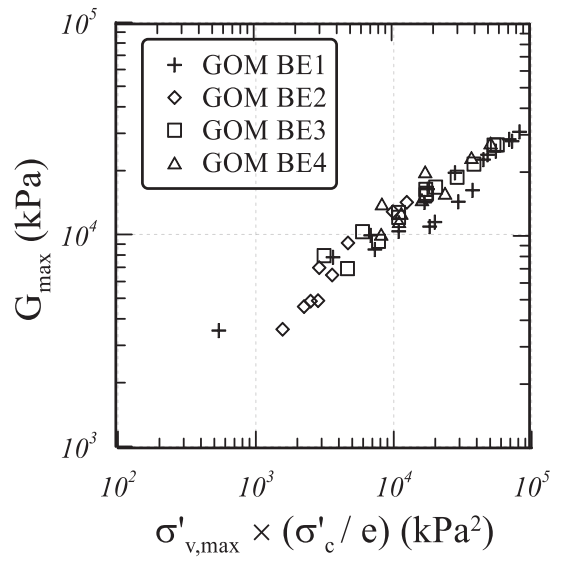

Fig. 1 Results of the bender element tests run on GOM clay

Table 1 Index properties of GOM clay and some details about bender element testing of GOM clay

\begin{tabular}{|c|c|c|c|c|c|c|c|c|c|c|c|c|c|c|}
\hline $\begin{array}{c}\text { Tet } \\
\text { name }\end{array}$ & $\begin{array}{c}\text { In- } \\
\text { situ } \\
\sigma_{\mathrm{p}} \\
\mathrm{kPa}\end{array}$ & $\begin{array}{c}\mathrm{W}_{\mathrm{o}} \\
\%\end{array}$ & $\begin{array}{c}\mathrm{W}_{\mathrm{L}} \\
\%\end{array}$ & $\begin{array}{c}\mathrm{W}_{\mathrm{p}} \\
\%\end{array}$ & $\begin{array}{c}\mathrm{I}_{\mathrm{p}} \\
\%\end{array}$ & $\mathrm{Gs}$ & $\mathrm{e}_{\mathrm{o}}$ & $\begin{array}{c}\mathrm{CF} \\
\%\end{array}$ & $\begin{array}{c}\text { Diameter } \\
\mathrm{mm}\end{array}$ & $\begin{array}{c}\text { Height } \\
\mathrm{mm}\end{array}$ & $\begin{array}{c}\text { Range } \\
\text { of } \sigma_{\mathrm{c}} \\
\mathrm{kPa}\end{array}$ & $\begin{array}{c}\text { Range } \\
\text { of } \\
\sigma_{\mathrm{v}, \max } \\
\mathrm{kPa}\end{array}$ & $\begin{array}{c}\text { Range } \\
\text { of } \\
\text { void } \\
\text { ratios }\end{array}$ & $\begin{array}{c}\mathrm{V}_{\mathrm{s}} \\
\text { measurements }\end{array}$ \\
\hline $\begin{array}{c}\text { GOM } \\
\text { BE1 }\end{array}$ & 15 & 88.2 & 83.8 & 34.3 & 49.5 & 2.77 & 2.443 & 72 & 70.4 & 146.7 & $34-314$ & $34-314$ & $\begin{array}{c}1.206- \\
2.108\end{array}$ & 18 \\
\hline $\begin{array}{c}\text { GOM } \\
\text { BE2 }\end{array}$ & 66 & 98.4 & 92.1 & 36.2 & 55.9 & 2.76 & 2.715 & 71 & 67.9 & 135.2 & $24-145$ & $74-145$ & $\begin{array}{c}1.695- \\
2.109\end{array}$ \\
\hline $\begin{array}{c}\text { GOM } \\
\text { BE3 }\end{array}$ & 51 & 111.0 & 103.4 & 41.4 & 62.0 & 2.77 & 3.074 & 83 & 71.0 & 153.1 & $42-251$ & $76-251$ & $1.206-$ & 14 \\
\hline $\begin{array}{c}\text { GOM } \\
\text { BE4 }\end{array}$ & 117 & 66.8 & 69.4 & 33.8 & 35.6 & 2.75 & 1.836 & 70 & 71.7 & 145.0 & $41-248$ & $\begin{array}{c}117- \\
248\end{array}$ & $\begin{array}{c}1.108- \\
1.396\end{array}$ \\
\hline
\end{tabular}




\section{Database and proposed relationships}

To validate Equation 5 for a range of $\mathrm{I}_{\mathrm{p}}$ (note that the $\mathrm{BE}$ tests on GOM clay involved similar plasticity index), the authors collected a database of several clays from around the world with field and laboratory measurements of $\mathrm{V}_{\mathrm{s}}$ or $\mathrm{G}_{\max }$ on intact and reconstituted specimens having a range of $\mathrm{I}_{\mathrm{p}}$ and overconsolidation ratio $\left(\mathrm{OCR}=\sigma_{\mathrm{p}}^{\prime} / \sigma_{\mathrm{v}}^{\prime}\right)$. Table 2 , through Table 5, respectively, provide details about the clays in the database having $\mathrm{I}_{\mathrm{p}}<30 \%, 30 \% \leq \mathrm{I}_{\mathrm{p}}<50 \%$, $50 \% \leq \mathrm{I}_{\mathrm{p}}<80 \%$ and $80 \% \leq \mathrm{I}_{\mathrm{p}}<120 \%$. (Note that $\mathrm{RC}=$ resonant column, $\mathrm{BE}=$ bender elements, $\mathrm{CH}=$ cross-hole, $\mathrm{DH}=$ down-hole, $\mathrm{SC}=$ seismic cone, $\mathrm{CTX}=$ cyclic triaxial, $\mathrm{cDSS}=$ cyclic direct simple shear, $\mathrm{TS}=$ torsional shear, SASW = spectral analysis of surface waves, MASW = multi-channel analysis of surface waves.)

Table 2 Database of clays with $\mathrm{I}_{\mathrm{p}}<30 \%$

\begin{tabular}{|c|c|c|c|}
\hline Name & Test & $\begin{array}{l}\mathbf{I}_{\mathbf{p}} \\
\%\end{array}$ & Reference \\
\hline $\begin{array}{c}\text { Drammen } \\
\text { Clay }\end{array}$ & $\begin{array}{l}\mathrm{RC} \text { and } \\
\mathrm{BE}\end{array}$ & 27 & $\begin{array}{c}\text { Dyvik and Olsen (1989), } \\
\text { Dyvik et al. (1987) }\end{array}$ \\
\hline $\begin{array}{l}\text { Agios } \\
\text { Stefanos } \\
\text { Clay }\end{array}$ & $\mathrm{CH}$ & 27 & Bouckovalas et al. (1989) \\
\hline $\begin{array}{l}\text { Drammen } \\
\text { Clay }\end{array}$ & $\mathrm{SC}$ & $\begin{array}{l}23 \\
(14- \\
33)\end{array}$ & $\begin{array}{c}\text { Larsson and Mulabdić } \\
\text { (1991), Bjerrum (1967), } \\
\text { Lacasse and Lunne (1983), } \\
\text { Eidsmoen et al. (1985) }\end{array}$ \\
\hline $\begin{array}{l}\text { Honmoku } \\
\text { Clay }\end{array}$ & $\begin{array}{l}\mathrm{RC} \text { and } \\
\mathrm{CTX}\end{array}$ & $0-25$ & Zen et al. (1978) \\
\hline $\begin{array}{l}\text { Jiangsu } \\
\text { Clays }\end{array}$ & $\begin{array}{l}\mathrm{CH}, \mathrm{DH}, \\
\mathrm{SASW} \\
\mathrm{SC}\end{array}$ & $8-27$ & Cai et al. (2014) \\
\hline $\begin{array}{l}\text { Offshore } \\
\text { New Jersey } \\
\text { Clay }\end{array}$ & $\mathrm{RC}$ & $12-22$ & $\begin{array}{l}\text { Koutsoftas and Fischer } \\
\qquad(1976,1980)\end{array}$ \\
\hline $\begin{array}{l}\text { Norwegian } \\
\text { Clays }\end{array}$ & $\begin{array}{l}\text { MASW, } \\
\text { CH, } \\
\text { SASW }\end{array}$ & $0-20$ & $\begin{array}{l}\text { L'Heureux and Long } \\
\qquad(2017)\end{array}$ \\
\hline $\begin{array}{l}\text { Dragvoll } \\
\text { Clay }\end{array}$ & SASW & $3-11$ & $\begin{array}{l}\text { Montafia (2013), } \\
\text { L'Heureux and Long } \\
(2017)\end{array}$ \\
\hline Välen Clay & MASW & $16-20$ & $\begin{array}{l}\text { Long et al. (2012), } \\
\text { L’Heureux and Long } \\
\text { (2017), Sauvin et al. } \\
\text { (2011) }\end{array}$ \\
\hline Klett Clay & MASW & 4 & $\begin{array}{l}\text { Amundsen et al. (2016), } \\
\text { L'Heureux and Long } \\
\text { (2017) }\end{array}$ \\
\hline Esp Clay & $\begin{array}{l}\text { MASW, } \\
\text { SC }\end{array}$ & $4-9$ & $\begin{array}{c}\text { Montafia (2013), } \\
\text { L'Heureux and Long } \\
\text { (2017) }\end{array}$ \\
\hline Tiller Clay & $\begin{array}{l}\text { MASW, } \\
\mathrm{CH}, \mathrm{SC}\end{array}$ & $5-10$ & $\begin{array}{l}\text { Gylland et al. (2013), } \\
\text { L'Heureux and Long } \\
\text { (2017) }\end{array}$ \\
\hline $\begin{array}{l}\text { Mediterra- } \\
\text { nean Clays }\end{array}$ & $\mathrm{RC}$ & $1-29$ & Vrettos and Savidis (1999) \\
\hline Belgian Silt & $\mathrm{SC}$ & $10-13$ & Gilles et al. (1991) \\
\hline
\end{tabular}

Table 3 Database of clays with $30 \% \leq \mathrm{I}_{\mathrm{p}}<50 \%$

\begin{tabular}{|c|c|c|c|}
\hline Name & Test & $\begin{array}{l}\mathbf{I}_{\mathbf{p}} \\
\% \\
\end{array}$ & Reference \\
\hline $\begin{array}{l}\text { Offshore } \\
\text { Clays }\end{array}$ & $\begin{array}{l}\mathrm{RC}, \\
\mathrm{cDSS}\end{array}$ & $39(30-50)$ & Kagawa (1992) \\
\hline $\begin{array}{l}\text { Skå-Edeby } \\
\text { Clay }\end{array}$ & $\mathrm{SC}$ & $40(30-55)$ & $\begin{array}{l}\text { Larsson and Mulabdić } \\
\qquad(1991)\end{array}$ \\
\hline $\begin{array}{l}\text { Norrköping } \\
\text { Clay }\end{array}$ & $\mathrm{SC}$ & $41(32-52)$ & $\begin{array}{l}\text { Larsson and Mulabdić } \\
\text { (1991), Möller (1991) }\end{array}$ \\
\hline $\begin{array}{l}\text { Bäckebol } \\
\text { Clay }\end{array}$ & $\mathrm{SC}$ & $41(32-49)$ & $\begin{array}{c}\text { Larsson and Mulabdić } \\
\text { (1991), Larsson (1975), } \\
\text { Sälfors (1975), Fellenius } \\
\text { (1971) }\end{array}$ \\
\hline Macao Clay & $\mathrm{BE}, \mathrm{CH}$ & 34 & Lok et al. (2008) \\
\hline $\begin{array}{l}\text { Bangkok } \\
\text { Clay }\end{array}$ & $\mathrm{SC}, \mathrm{DH}$ & $31(7-45)$ & $\begin{array}{l}\text { Likitlersuang et al. } \\
\text { (2013), Horpibulsuk et al. } \\
\text { (2007), Ashford et al. } \\
\text { (1996) }\end{array}$ \\
\hline Macao Clay & $\mathrm{BE}$ & $33(32-34)$ & $\begin{array}{c}\text { Lok et al. (2016), Lok et } \\
\text { al. (2008) }\end{array}$ \\
\hline $\begin{array}{l}\text { Honmoku } \\
\text { Clay }\end{array}$ & $\begin{array}{l}\mathrm{RC} \\
\mathrm{CTX}\end{array}$ & $38-46$ & Zen et al. (1978) \\
\hline $\begin{array}{c}\text { Offshore } \\
\text { New Jersey } \\
\text { Clay }\end{array}$ & $\mathrm{RC}$ & $32-59$ & $\begin{array}{l}\text { Koutsoftas and Fischer } \\
(1976,1980)\end{array}$ \\
\hline $\begin{array}{c}\text { Western } \\
\text { Greece } \\
\text { Coast Clay }\end{array}$ & $\mathrm{RC}$ & $31-40$ & $\begin{array}{l}\text { Vrettos and Savidis } \\
\text { (1999) }\end{array}$ \\
\hline
\end{tabular}

Table 4 Database of clays with $50 \% \leq \mathrm{I}_{\mathrm{p}}<80 \%$

\begin{tabular}{|c|c|c|c|}
\hline Name & Test & $\begin{array}{l}\mathbf{I}_{\mathbf{p}} \\
\%\end{array}$ & Reference \\
\hline $\begin{array}{c}\text { Offshore } \\
\text { Clays }\end{array}$ & $\mathrm{RC}$ & 54 & Kagawa (1992) \\
\hline $\begin{array}{l}\text { Lilla } \\
\text { Mellösa } \\
\text { Clay }\end{array}$ & $\mathrm{SC}$ & $\begin{array}{l}61(48- \\
73)\end{array}$ & $\begin{array}{c}\text { Larsson and Mulabdić } \\
\text { (1991) }\end{array}$ \\
\hline Tuve Clay & $\mathrm{SC}$ & $\begin{array}{l}52(45- \\
55)\end{array}$ & $\begin{array}{c}\text { Larsson and Mulabdić } \\
\text { (1991) }\end{array}$ \\
\hline Välen Clay & $\mathrm{SC}$ & $\begin{array}{c}74(64- \\
86)\end{array}$ & $\begin{array}{c}\text { Larsson and Mulabdić } \\
\text { (1991) }\end{array}$ \\
\hline $\begin{array}{l}\text { Bäckebol II } \\
\text { Clay }\end{array}$ & $\mathrm{SC}$ & $\begin{array}{c}53(44- \\
66)\end{array}$ & $\begin{array}{c}\text { Andréasson (1979), } \\
\text { Torstensson (1973), } \\
\text { Larsson (1975), Sälfors } \\
\text { (1975) }\end{array}$ \\
\hline $\begin{array}{l}\text { Bäckebol I } \\
\text { Clay }\end{array}$ & $\mathrm{SC}$ & $\begin{array}{c}56(51- \\
63)\end{array}$ & $\begin{array}{c}\text { Andréasson (1979), } \\
\text { Torstensson (1973), } \\
\text { Larsson (1975), Sälfors } \\
\text { (1975) }\end{array}$ \\
\hline Välen Clay & $\mathrm{SC}$ & $\begin{array}{l}89(80- \\
97)\end{array}$ & $\begin{array}{c}\text { Andréasson (1979), } \\
\text { Torstensson (1973), } \\
\text { Larsson (1975), Sälfors } \\
\text { (1975) }\end{array}$ \\
\hline $\begin{array}{l}\text { Teganuma } \\
\text { Clay }\end{array}$ & CTX & $40-103$ & $\begin{array}{l}\text { Kokusho et al. (1982), } \\
\text { Kukusho (1980) }\end{array}$ \\
\hline $\begin{array}{l}\text { Fucino } \\
\text { Clay }\end{array}$ & $\begin{array}{l}\mathrm{CH}, \mathrm{DH}, \\
\text { SC, } \\
\text { SASW }\end{array}$ & $46-103$ & Burghignoli et al. (1991) \\
\hline $\begin{array}{l}\text { Osaka Bay } \\
\text { Clay }\end{array}$ & $\mathrm{RC}$ & $50-83$ & $\begin{array}{c}\text { Ohneda et al. (1984), } \\
\text { Horie et al. (1984), Ishii } \\
\text { et al. (1984), Tsuchida et } \\
\text { al. (1984) }\end{array}$ \\
\hline
\end{tabular}


Table 5 Database of clays with $80 \% \leq \mathrm{I}_{\mathrm{p}}<120 \%$ (+Organics)

\begin{tabular}{|c|c|c|c|}
\hline Name & Test & $\begin{array}{l}I_{p} \\
\%\end{array}$ & Reference \\
\hline $\begin{array}{l}\text { Lilla Mellösa } \\
\text { Clay }\end{array}$ & $\overline{\mathrm{SC}}$ & $\begin{array}{c}85(82- \\
87)\end{array}$ & $\begin{array}{c}\text { Larsson and Mulabdić } \\
\text { (1991) }\end{array}$ \\
\hline $\begin{array}{l}\text { Vallda } 6 / 900 \\
\text { Clay }\end{array}$ & $\mathrm{SC}$ & $\begin{array}{l}101 \\
(85- \\
109)\end{array}$ & $\begin{array}{c}\text { Larsson and Mulabdić } \\
\text { (1991) }\end{array}$ \\
\hline $\begin{array}{l}\text { Vallda } 7 / 600 \\
\text { Clay }\end{array}$ & $\mathrm{SC}$ & $\begin{array}{l}84(71- \\
95)\end{array}$ & $\begin{array}{l}\text { Larsson and Mulabdić } \\
\text { (1991) }\end{array}$ \\
\hline $\begin{array}{l}\text { Teganuma } \\
\text { Clay }\end{array}$ & CTX & $40-103$ & $\begin{array}{l}\text { Kokusho et al. (1982), } \\
\text { Kukusho (1980) }\end{array}$ \\
\hline $\begin{array}{l}\text { Hokkaido } \\
\text { Peats }\end{array}$ & TS & $\begin{array}{l}\text { Organic } \\
\begin{array}{c}(\mathrm{Li}=18 \\
-95 \%)\end{array}\end{array}$ & $\begin{array}{c}\text { Hayashi and Nishimoto } \\
\text { (2015) }\end{array}$ \\
\hline $\begin{array}{l}\text { Hachirogata } \\
\text { Clay }\end{array}$ & $\mathrm{SC}, \mathrm{TS}$ & $85-152$ & $\begin{array}{l}\text { Shibuya et al. (1994), } \\
\text { Tanaka and Tanaka } \\
\text { (1993), Tang et al. (1993) }\end{array}$ \\
\hline
\end{tabular}

Fig 2 plots the data collected in the 4 given plasticity bins $(<30 \%, 30-50 \%, 50-80 \%, 80-120 \%)$ in $\mathrm{G}_{\max }-$ $\sigma_{\mathrm{p}}^{\prime} \times\left(\sigma_{\mathrm{v}}^{\prime} / \mathrm{e}\right)$ space. The field data on $\sigma_{\mathrm{p}}^{\prime}$ come from laboratory oedometer tests on undisturbed samples, and $\sigma_{v}^{\prime}$ were estimated considering the soil profile at a given site and the position of the water table. Note that $\sigma_{\mathrm{p}}^{\prime}$ is the equivalent of $\sigma_{v, \max }^{\prime}$ of a specimen consolidated to the virgin compression zone and $\sigma_{\mathrm{v}}^{\prime}$ is the equivalent of $\sigma_{\mathrm{c}}^{\prime}$ for a specimen consolidated under equal all-around pressure. For specimens consolidated under anisotropic conditions, $\sigma_{c}^{\prime}$ was used to imply mean effective stress. Also shown in the plots are the trendlines and the predictive equations for $\mathrm{G}_{\max }$.

The A parameter in Equation 5 for $\mathrm{I}_{\mathrm{p}}<30 \%, 30 \% \leq \mathrm{I}_{\mathrm{p}}$ $<50 \%, 50 \% \leq \mathrm{I}_{\mathrm{p}}<80 \%$ and $80 \% \leq \mathrm{I}_{\mathrm{p}}<120 \%$ were respectively 288, 226, 184 and 149. Equation 9 shows the relationship between the A parameter and plasticity index $(\%)$.

$$
A=314 \times \exp \left(-0.008 I_{p}\right)
$$

Although effective mean stress $\sigma_{\text {mean }}^{\prime}$ is generally a more powerful tool to quantify $G_{\max }$, knowledge of the coefficient of earth pressure at rest $\mathrm{k}_{0}$ is required because it influences $\mathrm{G}_{\max }$ (e.g., [17], [18]). However, information about $\mathrm{k}_{0}$ is not always readily available. Therefore, it was decided to adopt $\sigma_{v}^{\prime}$ or $\sigma_{c}^{\prime}$ in proposing the relationships for $\mathrm{G}_{\text {max }}$ because $\mathrm{G}_{\max }{ }^{\text {hv }} \approx \mathrm{G}_{\text {max }}{ }^{\text {hh }} \approx \mathrm{G}_{\text {max }}{ }^{\mathrm{vv}}$ for normally to moderately overconsolidated soft clays (e.g., [27]) and it is easier to define $\sigma_{v}^{\prime}$ than $\sigma_{h}^{\prime}$. The influence of $k_{0}$ on $G_{\max }$ is probably why the bender element tests run on GOM clay lie slightly below the predictive trendlines for $30 \% \leq$ $\mathrm{I}_{\mathrm{p}}<50 \%$ and $50 \% \leq \mathrm{I}_{\mathrm{p}}<80 \%$. All the BE tests had $\mathrm{k}_{0}=$ 1 , whereas soft clays in the field typically have $\mathrm{k}_{0}=0.55$ -1.0 .

By using Equation 5 and Equation 9, and provided $\sigma_{v}^{\prime}, \sigma_{p}^{\prime}$, e and $I_{p}$ are known, $G_{\max }$ of a clay can be effectively estimated. Likewise, if $\mathrm{G}_{\max }$ is known, an estimate of the preconsolidation pressure can be obtained.
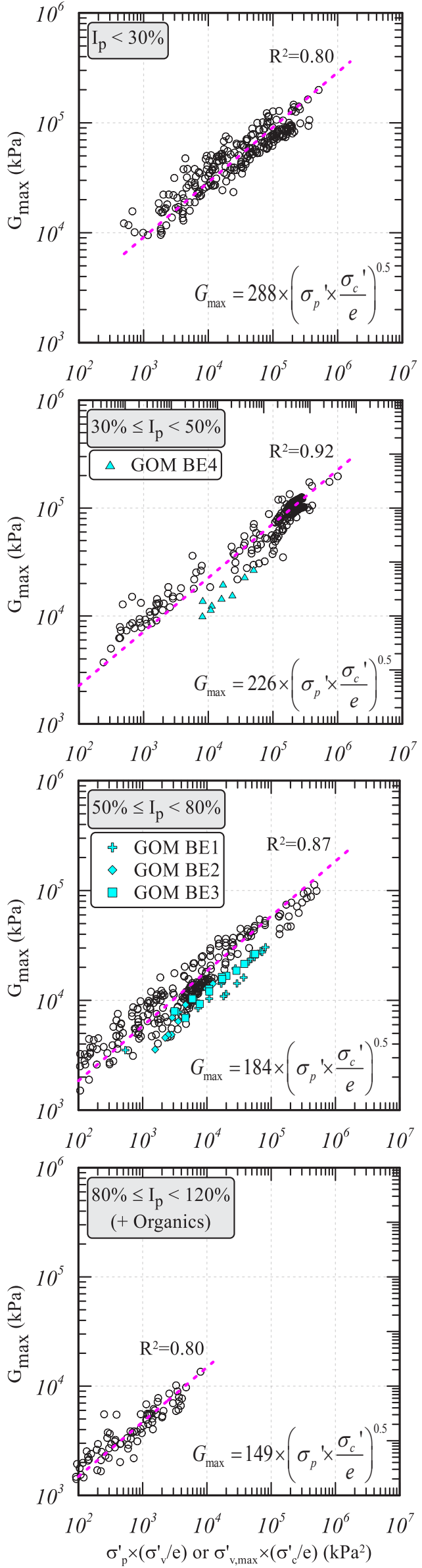

Fig 2 Relationships for $G_{\max }$ of clays with different plasticity 


\section{Conclusions}

Bender element tests performed on a Gulf of Mexico clay consolidated under equal all-around stresses and subjected to multiple load-unload loops were supplemented with a database of 40 clays of different plasticity index to illustrate that the small-strain shear modulus of clays depends on consolidation stress, plasticity index, preconsolidation stress, and void ratio. The authors used the database to propose a simple correlation between those parameters and the $G_{\max }$ of clays. It can be used to estimate $\mathrm{G}_{\max }$ if the stress states $\left(\sigma_{\mathrm{p}}^{\prime}\right.$ and $\left.\sigma_{\mathrm{c}}^{\prime}\right)$ and void ratio are known and vice versa.

\section{References}

1. Sagaseta, C. (1993). Predictive soil Mechanics: Soil properties and their measurement. Proceedings of the Wroth Memorial Symposium (eds. Houlsby, G. T. and Schofield, A. N.), Oxford. 19 - 49.

2. Donohue, S. and Long, M. (2010). Assessment of sample quality in soft clay using shear wave velocity and suction measurements. Géotechnique, Vol. 60 (11), 883 - 889. DOI: 10.1680/geot.8.T.007.3741

3. Burland, J. B. (1989). Ninth Laurits Bjerrum Memorial Lecture: Small is beautiful - the stiffness of soils at small strains. Canadian Geotechnical Journal, Vol. 26(4), 499 516. DOI: 10.1139/t89-064

4. Clayton, C. R. I. (2011). 50 $0^{\text {th }}$ Rankine Lecture - Stiffness at small strain: research and practice. Géotechnique, Vol. 61 (1), 5 - 37. DOI: 10.1680/geot.2011.61.1.5

5. Romo, M. P. and Seed, H. B. (1986). Analytical Modelling of Dynamic Soil Response in the Mexico Earthquake of September 19, 1985. Proceedings of the ASCE International Conference on the Mexico Earthquakes 1985, Mexico City, 148 - 162.

6. Hashash, Y. M. A., Dashti, S., Romero, M. I., Ghayoomi, M., and Musgrove, M. (2015). Evaluation of 1-D seismic site response modeling of sand using centrifuge experiments. Soil Dynamics and Earthquake Engineering, Vol. 78, 19-31.

7. Numanoglu, O. A., Hashash, Y. M. A., Cerna-Diaz, A., Olson, S. M., Bhaumik, L., Rutherford, C. J. and Weaver, T. (2017). Nonlinear 3-D Modeling of Dense Sand and the Simulation of a Soil-Structure System under MultiDirectional Loading. Geotechnical Frontiers 2017: Seismic Performance and Liquefaction. GSP 281, $379-388$.

8. Lawrence, F. V. Jr. (1965). Ultrasonic Shear Wave Velocities in Sand and Clay. Report 23, Response of Soils to Dynamic Loadings, directed by R. V. Whitman, Massachusetts Institute of Technology, Cambridge, Massachusetts.

9. Hardin, B. O. and Black, W. L. (1968). Vibration Modulus of normally consolidated clay. Journal of the Soil Mechanics and Foundations Division, ASCE, Vol. 94(2), $353-370$.

10. Atkinson, J. H. (1973). The deformation of undisturbed London Clay. Ph.D. thesis, University of London.

11. Andréasson, B. A. (1979). Deformation Characteristics of Soft, High-Plastic Clays under Dynamic Loading Conditions. M.S. Thesis, Chalmers University of Technology, Gothenburg.
12. Ohneda, H. Umehara, Y., Higuchi, Y. and Irisawa, K. (1984). Engineering Properties of Marine Clays in Osaka Bay (Part 4) Dynamic Stress-Strain and Strength properties. Technical Note of the Part and Airport Research Institute, No. 498 (in Japanese)

13. Larsson, R., and Mulabdić, M. (1991). Shear moduli in Scandinavian clays. Report No. 40, SGI, Linköping, 127 p.

14. Viggiani, G. (1992). Small strain stiffness of fine-grained soils. Ph.D. thesis, City University, London, U.K.

15. Tanaka, H., Tanaka, M., Iguchi, H. and Nishida, K. (1994). Shear modulus of soft clay measured by various kinds of tests. Proc. of the International Conference on Pre-Failure Deformation of Geomaterials (eds. Shibuya, S., Mitachi, T. and Miura, S.), Sapporo, Japan, 235-240.

16. Jamiolkowski, M., Lancellota, R. and Lo Presti, D. C. F. (1994). Remarks on the stiffness at small strain of six Italian clays. Proc.of the International Conference on PreFailure Deformation of Geomaterials (eds. Shibuya, S., Mitachi, T. and Miura, S.), Sapporo, Japan, 817 - 836.

17. Nishimura, S. (2006). Laboratory study on anisotropy of natural London clay. Ph.D. thesis, Imperial College London, U.K.

18. Anh-Minh, N. (2007). An investigation of the anisotropic stress-strain-strength characteristics of an Eocene clay. Ph.D. thesis, Imperial College London, U.K.

19. Wood, T. (2016). On the Small Strain Stiffness of Some Scandinavian Soft Clays and Impact on Deep Excavations. Ph.D. Thesis, Chalmers University of Technology, Sweden.

20. Carlton, B. D. and Pestana, J. M. (2012). Small Strain Shear Modulus of High and Low Plasticity Clays and Silts. Proceedings of the $15^{\text {th }}$ WCEE, Lisbon.

21. Agaiby, S. S. and Mayne, P. W. (2016). Use of shear wave velocity to estimate stress history and undrained shear strength of clays. Proceedings of the Geotechnical and Geophysical Site Characterisation 5 - (eds., Lehane, Acosta-Martínez and Kelly), Sydney, Australia, 461 - 466.

22. L'Heureux, J-S. and Long, M. (2017). Relationship between Shear-Wave Velocity and Geotechnical Parameters for Norwegian Clays. ASCE, Journal of Geotechnical and Geoenvironmental Engineering, Vol. 143(6), 04017013-1 - 04017013-20. DOI: 10.1061/(ASCE)GT.1943-5606.0001645.

23. Mitchell, J. K. and Soga, K. (2005). Fundamentals of Soil Behavior. $3^{\text {rd }}$ Edition, John Wiley \& Sons Inc., New York.

24. Terzaghi, K., Peck, R.B., and Mesri, G. (1996). Soil Mechanics in Engineering Practice. $3^{\text {rd }}$ Ed., Wiley, NY.

25. Wilson, S. and Dietrich, R. (1960). Effect of Consolidation Pressure on Elastic and Strength Properties of Clay. Proceedings Conference on Shear Strength of Cohesive Soils, Boulder, Colorado, $419-435$.

26. Silva, A. J. and Bryant, W. R. (2000). Jumbo Piston Coring in deep water Gulf of Mexico for seabed geohazard and geotechnical investigations. Proceedings of the 10th International Offshore and Polar Engineering Conference, Seattle, USA, $424-432$.

27. Butcher, A. P. and Powell, J. J. M. (1995). The effects of geological history on the dynamic stiffness in soils. Proc. of the $11^{\text {th }}$ European Conference on Soil Mechanics and Foundation Engineering., Vol. 1, 27 - 36. 